\title{
Neonicotinoids and fipronil concentrations in honeybees associated with pesticide use in Brazilian agricultural areas
}

\author{
Dayson Castilhos $^{1}$, Jeferson L. D. Dombroski ${ }^{2}$, Genevile C. Bergamo ${ }^{3}$, \\ Kátia P. Gramacho ${ }^{1}$, Lionel S. GonÇalves ${ }^{1,4}$ \\ ${ }^{1}$ Programa de Pós-graduação em Ciência Animal, Universidade Federal Rural do Semi-Árido, Av. Francisco Mota, 572, \\ Mossoró, RN 59.625-900, Brazil \\ ${ }^{2}$ DCAF, Universidade Federal Rural do Semi-Árido, Mossoró, RN, Brazil \\ ${ }^{3}$ DCME, Universidade Federal Rural do Semi-Árido, Mossoró, RN, Brazil \\ ${ }^{4}$ FFCL, Universidade de São Paulo, Ribeirão Preto, SP, Brazil
}

Received 23 November 2018 - Revised 16 June 2019 - Accepted 5 July 2019

\begin{abstract}
Brazil leads global lists of honeybee colony losses in South America as well as pesticide use, according to a web-based survey (http://www.nobeenofood.com/beealert). In association with that survey, Africanized honeybee (Apis mellifera) samples were opportunistically collected when bee poisoning was apparently linked to pesticide use in crops. The objective was to determine concentrations of fipronil and neonicotinoids in live and dead honeybees, in areas where these compounds are widely used in agriculture. Pesticide residues in honeybees (54 live and 60 dead composite samples) were detected with mass spectrometry (UHPLC-MS/MS using QuEChERS methodology). Toxicological analyses in both matrices detected multiple contaminations with highest indices by fipronil with frequency of 55.3\% and amplitude $(0.7-23,539.7 \mathrm{ng} / \mathrm{g})$, thiamethoxam $20.2 \%(0.6-13.6 \mathrm{ng} / \mathrm{g})$, imidacloprid 3.5\% (4.5-16.2 ng/g), nitenpyram $1.8 \%(3.8-7.4 \mathrm{ng} / \mathrm{g})$, and thiacloprid $0.9 \%(1.6 \mathrm{ng} / \mathrm{g})$. Neonicotinoids and fipronil residues had higher frequencies and amplitudes in honeybees collected near sugarcane plantations and orange orchards in northwest São Paulo state and other agro-industrial rural landscapes across the country dominated with fields of soybean, corn, and tropical fruit crops. These systemic pesticides were presumed to be primary mechanisms of honeybee colony losses in Brazil, according to a recently published 5-year survey by the same authors and reinforced by current analyses.
\end{abstract}

\section{Apis mellifera / colony losses / pesticide / UHPLC-MS/MS / QuEChERS / rural landscapes}

\section{INTRODUCTION}

From 1965 to 2004, pesticide use in Brazil increased by $700 \%$, although agricultural area increased by only $78 \%$ (Spadotto 2006).

Electronic supplementary material The online version of this article (https://doi.org/10.1007/s13592-019-00676-x) contains supplementary material, which is available to authorized users.

Corresponding author: D. Castilhos, dayson.castilhos@ufersa.edu.br Manuscript editor: James Nieh This article has been updated to render correct acknowledgements and references.
Furthermore, insecticide use increased by $>150 \%$ over the last 15 years, with current use greater than any other country (dos Santos et al. 2018). In 2014, pesticide use in Brazilian agriculture exceeded $1 \times$ $10^{6}$ tons, an average of $5.2 \mathrm{~kg}$ per capita (Bombardi 2017; INCA 2015; Rigotto et al. 2014). There were $\sim 9 \times 10^{8} \mathrm{~L}$ of pesticides sprayed in 2015 in the three Brazilian states (Mato Grosso, Paraná, and Rio Grande do Sul) regarded as leading producers of soybeans (Pignati et al. 2017).

Sanches et al. (2009) concluded that although "use of systemic insecticides in insect control in citrus seedlings reached efficiency between 95 and 100\%," they devastated non-target organisms 
and the environment. Negative effects of systemic insecticides on biomes and organisms have not been completely elucidated (Bernhardt et al. 2017; Chagnon et al. 2015; Köhler and Triebskorn 2013). Regardless, indiscriminate use clearly causes great environmental damage (Maini et al. 2010; Stevens and Jenkins 2014) and contamination of biomes and biota affect pollination and beekeeping, plus humans (Bombardi 2017; Gonçalves 2012a, b; Rigotto et al. 2014).

In this study, we focused on neonicotinoids and fipronil due to (1) limited resources and (2) similarities in toxicity, chemical profiles, and presence in environment, as neonicotinoids and fipronil account for one-third of the global insecticide market (Simon-Delso et al. 2015). Their modes of action (MoA), practicality of application, combined with some insects having resistance to other classes of insecticides (Marrs 1993), have contributed to their popularity.

Neonicotinoids are neurotoxic substances; their agonist MoA overwhelms cation channel openings of nicotine acetylcholine receptors ( $n A C h R s$ ) of invertebrates (Casida and Durkin 2013).

Due to their high insect toxicity $\left(\mathrm{LD}_{50}\right.$ for bees $\sim 5 \mathrm{ng} /$ bee and $\mathrm{a} \mathrm{LC}_{50}$ of 5-10 ng/g; Suchail et al. 2000), neonicotinoids are the most commercially available insecticides. Plant concentrations between 5 and $10 \mathrm{ng} / \mathrm{g}$ will kill parasitic or visiting insects (Byrne and Toscano 2006; Castle et al. 2005).

Antagonistically, fipronil blocks inhibitory receptors, leading to neuronal hyper-excitation due to accumulation of a neurotransmitter (GABA) in synaptic junctions.

There are indications that widespread use of neonicotinoid and fipronil insecticides in agricultural landscapes is associated with intense colony loss events nationwide (Castilhos et al. 2019; Gonçalves and Castilhos 2015a, b; Pires et al. 2016; UNESP, UFSCAR 2018).

The objective of this study was to detect and quantify residues of neonicotinoids and fipronil, in dead managed Africanized honeybees (Apis mellifera ) samples, collected after beekeepers' communication of aerial or mechanical exposure, providing further evidence that the widespread use of pesticides (INCA 2015) is posing risks to Brazilian beekeeping, as in other countries (Castillo-Diaz et al. 2017; Douglas and Tooker
2015; EFSA 2016a, b; Pisa et al. 2017; Schaafsma et al. 2016; Wood and Goulson 2017). Samples of live, apparently healthy honeybees were also collected as a comparison.

\section{MATERIALS AND METHODS}

\subsection{Sample collection}

All samples were located through BEE ALERT online survey (http://www.nobeenofood. com/beealert). Thirty-eight apiaries were located by Global Positioning System (GPS), highlighted on a map (Figure 1), and described in detail (Table S.M. 1-Supplementary Material) where 114 samples were collected.

Sixty samples of dead Africanized honeybees (Apis mellifera), suspected to be contaminated by pesticides, were collected with sterile spatulas and placed into sterile biological sample collectors. Symptoms of poisoned honeybees were massive numbers of dead bees inside hives or on the ground below the entrance and agonal honeybees near hives. Another 54 samples of apparently healthy honeybees were collected in apiaries without poisoning symptoms, within a maximum radius of $3 \mathrm{~km}$ of the affected apiaries. Approximately 200 honeybees were collected per sample. Samples were transported to the lab in styrofoam boxes containing dry ice, arriving within $24 \mathrm{~h}$ after collection. In the lab, they were stored at $-80^{\circ} \mathrm{C}$ during the collection interval (1-10 months) prior to chemical analyses.

Live and dead honeybee samples from seven states encompassing four regions were collected and submitted. Of 114 total samples, Midwest sent 60 (52.6\%); Southeast, 33 (29\%); Northeast, 9 (7.9\%); and South, 12 (10.5\%).

Analyses were done in LAEV-Laboratory of Plant Eco-physiology, UFERSA Department of Plant Sciences, using the QuEChERS method (Anastassiades et al. 2003), modified by David et al. (2015) and optimized by the authors to local environmental characteristics.

\subsection{Analytical standards and reagents}

Detailed chemical properties of neonicotinoids and fipronil, the most commonly used insecticides in Brazilian agricultural production, are shown 


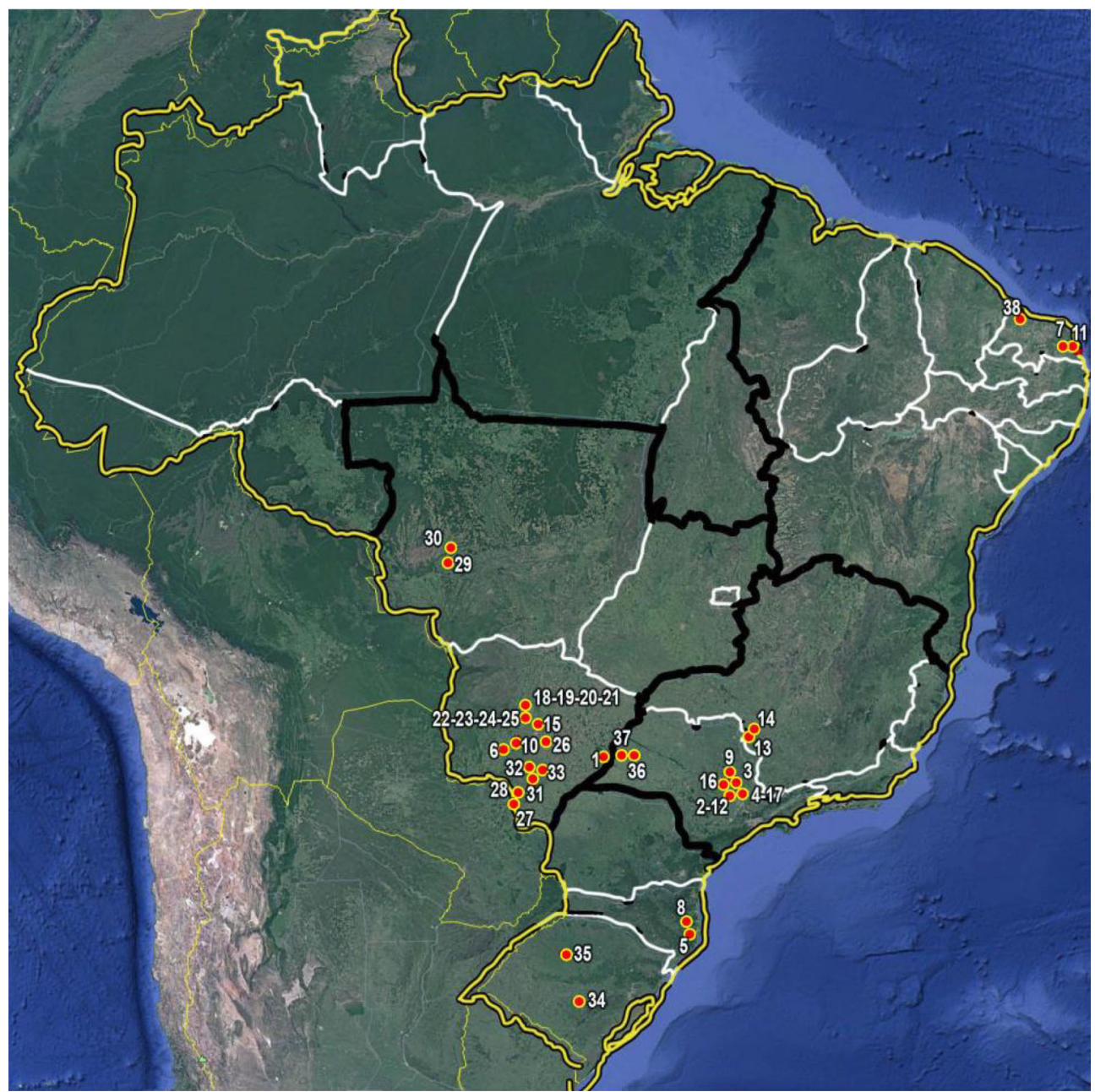

Yellow line $=$ country border; Black line $=$ region borders; White line $=$ state borders

Source: Cartographic base: Google Earth (2017), modified by author with surveyed data.

Figure 1. GPS distribution of collected samples for analysis. Yellow line, country border; black line, region borders; white line, state borders. Source: cartographic base, Google Earth (2017), modified by author with surveyed data.

(Table S.M. 2-Supplementary Material). Certified pesticide standards (acetamiprid, clothianidin, dinotefuran, imidacloprid, nitenpyram, thiacloprid, thiamethoxam, and fipronil), internal standards (IS) (clothianidin $\mathrm{d}_{3}$ and thiamethoxam $\mathrm{d}_{3}$ ), magnesium sulfate, sodium acetate, formic acid, ammonium formate, Supelclean ${ }^{\mathrm{TM}} \mathrm{PSA} / \mathrm{SPE}$ (primary, secondary amide), Discovery® DSC-18/SPE (C-18 silica gel based material), HPLC grade acetonitrile, and HPLC grade ultrapure water were purchased from
Sigma-Aldrich do Brasil Ltda. (São Paulo, SP, Brazil). All compounds were $>99 \%$ pure.

Individual stock solutions $\left(1 \mathrm{mg} \mathrm{mL} \mathrm{m}^{-1}\right)$ of insecticide standards and internal standards were prepared in acetonitrile (ACN).

\subsection{Sample preparation}

For analysis, five frozen $\left(-25^{\circ} \mathrm{C}\right)$ honeybees were weighed and ground. Bees were placed in a micro homogenization tube with sealing ring and 
three 316L steel beads. Dry maceration (3000 cycles/min for $3 \mathrm{~min}$ ) was done in a Beadbug micro homogenizer, Model D1030-E (Universal Medical, Norwood, MA, USA).

After maceration, the average mass of an Africanized honeybee $(\sim 100 \mathrm{mg})$ was removed from each tube and placed in a clean micro tube. Then, $10 \mu \mathrm{L}$ of IS (Thiamethoxam $\mathrm{d}_{3}$, Clothianidin $\left.\mathrm{d}_{3}\right)\left(250 \mathrm{ng} \mathrm{mL}^{-1}\right.$ each) and ultrapure water $(400 \mu \mathrm{L})$ added, contents homogenized for $30 \mathrm{~s}$, standard ACN, HPLC grade $(500 \mu \mathrm{L})$ added, homogenized again for $30 \mathrm{~s}$, and finally contents were vortexed for $10 \mathrm{~min}$. Then, $250 \mathrm{mg}$ of magnesium sulfate $\left(\mathrm{MgSO}_{4}\right) /$ sodium acetate $\left(\mathrm{C}_{2} \mathrm{H}_{3} \mathrm{NaO}_{2}\right)(4: 1)$ was added. The sample was immediately homogenized for $30 \mathrm{~s}$ (to avoid solidification of magnesium sulfate), agitated for $10 \mathrm{~min}$, and then placed in a centrifuge (Spinlab, model SL-SGR) and subjected to $13,000 \mathrm{~g}$ for $10 \mathrm{~min}$ at $20^{\circ} \mathrm{C}$.

After centrifugation, the supernatant was withdrawn with a digital pipette $(\sim 450 \mu \mathrm{L})$ and placed in a flip-cap centrifuge micro tube $(2 \mathrm{~mL})$ containing $150 \mathrm{mg}$ of $\mathrm{MgSO}_{4} / \mathrm{Supelclean}^{\mathrm{TM}} \mathrm{PSA} /$ Discovery® DSC-18 (1:1:1) for removal of residues, lipids, water, and pigments. The sample was homogenized for $30 \mathrm{~s}$ (3000 cycles/min) and agitated for $10 \mathrm{~min}$ (300 cycles/min), filtered on a hydrophilic PTFE membrane syringe filter $(0.22 \mu \mathrm{m}, 13 \mathrm{~mm})$, and stored in a flip-cap micro tube $(1.5 \mathrm{~mL})$. The volume recovered $(\sim 250 \mu \mathrm{L})$ was placed in a freezer overnight $\left(-25^{\circ} \mathrm{C}\right)$ to suspend and separate any lipid residues.

If lipid formation was observed, analyte was withdrawn with a digital pipette $(\sim 250 \mu \mathrm{L})$ and transferred to another micro tube for drying. In the absence of lipid formation, the sample was evaporated in nitrogen $\left(\mathrm{N}_{2}\right)$ and reconstituted in $120 \mu \mathrm{L}$ of $\mathrm{ACN} / \mathrm{H}_{2} \mathrm{O}$ (30:70) and transferred to the glass vial with an insert for analysis. Reconstitution of the extraction in $\mathrm{ACN}: \mathrm{H}_{2} \mathrm{O}(30: 70)$ was based on neonicotinoids and fipronil having adequate solubility in hydrophobic solvents.

\subsection{UHPLC}

Ultra high-performance liquid chromatography (UHPLC-NexeraX2-Shimadzu) combined with triple quadrupole mass spectrometer (LCMS8040-Shimadzu) was used to detect pesticide residues in honeybee samples.
Samples were separated on Shim-pack XRODS III-Shimadzu UHPLC C-18 $(1.6 \mu \mathrm{m} \times$ $2.0 \times 75 \mathrm{~mm}$ ) chromatographic column. Column temperature was maintained at $35{ }^{\circ} \mathrm{C}$. Injection volume was $5 \mu \mathrm{L}$ and the mobile phase was composed of solution A $\left(5 \%\right.$ ACN, $95 \% \mathrm{H}_{2} \mathrm{O}$, $5 \mathrm{mM} \mathrm{NH} \mathrm{HCO}_{2}$-ammonium formate, and $0.1 \% \mathrm{HCOOH}$ - formic acid) and solution $\mathrm{B}$ ( $95 \%$ A C N , $5 \% \quad \mathrm{H}_{2} \mathrm{O}, 5 \mathrm{~m} \mathrm{M}$ $\mathrm{NH}_{4} \mathrm{HCO}_{2}$-ammonium formate, and $0.1 \%$ $\mathrm{HCOOH}$ - formic acid) in a gradient.

The chromatographic run started with $10 \% \mathrm{~B}$, rising to $30 \%$ at $10 \mathrm{~min}$ and then to $100 \%$ at $12 \mathrm{~min}$. It was maintained at $100 \%$ for $7 \mathrm{~min}$, returned to $10 \%$ at $19 \mathrm{~min}$ and $10 \mathrm{~s}$, and held at $10 \%$ for a further $3 \mathrm{~min}$ and $20 \mathrm{~s}$. Total run time was $22.5 \mathrm{~min}$.

\subsection{MS/MS parameters}

Quantification was done in MRM (multiple reaction monitoring) using the automated, positive electron ionization (ESI) ionic mode for neonicotinoids and negative for fipronil. Product ion Q3(1) was used for quantification and Q3(2) for qualification. Fragmentations of protonated $[\mathrm{M}+\mathrm{H}]^{+}$or deprotonated molecular ions [M $\mathrm{H}]^{+}$were controlled. De-clustering potential $(0-$ $40 \mathrm{~V})$ and collision energy $(10-40 \mathrm{eV})$ were selected (Table S.M. 3).

\subsection{Method validation}

Method parameters (recoveries, precision, repetitivity, repeatability, linearity, LOQ, and matrix effect of the final method) (Table I) were explained spiking blank honeybees collected from local organic honey producers and previously checked for the absence of neonicotinoids and fipronil (control) according to the EC guidance document SANTE/ 11813/2017 (European Commission 2017).

Method validation followed guidance document SANTE/11813/2017 and was replicated 5 times (5 subsamples analyzed with 5 repetitions).

Blank honeybee extractions were used to define the recoveries in spiked 5 and $50 \mathrm{ng} / \mathrm{g}$ for each compound, and UHPLC-MS/MS calibration through matrix standard solution. 
Table I.. Performance of the method for the analyzed pesticides in Africanized honeybee (Apis mellifera).

\begin{tabular}{|c|c|c|c|c|c|c|c|c|}
\hline \multirow[t]{3}{*}{ Compound } & \multicolumn{2}{|l|}{ Linearity } & \multirow{3}{*}{$\begin{array}{l}\text { Matrix effect } \\
\text { (\%) }\end{array}$} & \multicolumn{5}{|c|}{ Recoveries } \\
\hline & \multirow[t]{2}{*}{ Range (ng/g) } & \multirow[t]{2}{*}{$R^{2}$} & & \multicolumn{2}{|l|}{$5 \mathrm{ng} / \mathrm{g}$} & \multicolumn{2}{|l|}{$50 \mathrm{ng} / \mathrm{g}$} & \multirow[t]{2}{*}{ LOQ (ng/g) } \\
\hline & & & & $A v(\%)$ & $r s d(\%)$ & $A v(\%)$ & $r s d(\%)$ & \\
\hline Acetamiprid & $1-200$ & 0.999 & 18.3 & 77.0 & 13.6 & 80.9 & 12.9 & 0.11 \\
\hline Clothianidin & $1-200$ & 0.999 & -14.9 & 82.6 & 18.1 & 97.1 & 4.7 & 1.88 \\
\hline Dinotefuran & $1-200$ & 0.999 & 12.5 & 93.7 & 3.7 & 93.2 & 7.3 & 0.89 \\
\hline Imidacloprid & $1-200$ & 0.999 & -18.3 & 74.5 & 17.9 & 93.3 & 5.6 & 2.36 \\
\hline Nitenpyram & $1-200$ & 0.999 & 4.9 & 93.7 & 4.5 & 97.3 & 3.1 & 1.01 \\
\hline Thiacloprid & $1-200$ & 0.999 & -19.9 & 79.1 & 19.8 & 87.3 & 11.4 & 0.22 \\
\hline Thiamethoxam & $1-200$ & 0.999 & -12.5 & 85.4 & 17.8 & 97.1 & 2.6 & 0.54 \\
\hline Fipronil & $1-200$ & 0.991 & -6.1 & 114.8 & 12.3 & 115.5 & 13.2 & 0.10 \\
\hline
\end{tabular}

$R^{2}$, determination coefficients, calculated from calibration curves using 8 matrix-matched calibration standards; matrix effect refers to percentual differences between calibration curves in solvent and in matrix; $A v$, percentual average $(n=5$ replicates) recovery (acceptable $70<\mathrm{Av}<120 \%$ ); $r s d$, precision of the method given by the relative standard deviation (acceptable $<20 \%$ ); $L O Q$, limit of quantification

Analyte concentrations were determined from a calibration curve using linear regression analysis of peak area ratio versus concentration ratio (native analyte to internal standard). Eight calibration curve points $(1,5,10,15,25,50,100$, and $200 \mathrm{ng} /$ $\mathrm{g}$ in $\mathrm{ACN} / \mathrm{H}_{2} \mathrm{O}(30: 70)$ ) were used to cover the range of concentrations observed in various matrices for all components. Linearity followed guidance document SANTE/11813/2017, with linearity coefficient $R^{2}>0.99$. MRM transition parameters, retention and acquisition, were optimized for pesticide standards of interest and internal standards for quantification of the analytes (Table S.M. 3 - Supplementary Material).

Pesticides identified in the analyses were seven neonicotinoids (acetamiprid, clothianidin, dinotefuran, imidacloprid, nitenpyram, thiacloprid, thiamethoxam) and one phenylpyrazole (fipronil).

\subsection{Quality control}

Identities of neonicotinoids and fipronil were evaluated by comparing ratios of MRM transitions in samples and pure standards. The mix of calibration standards was injected before and after all batches of samples to monitor changes in sensitivity prior to analysis of the next batch. Quality control samples (standard solutions) were injected every 10 samples to monitor sensitivity changes during analysis of each batch. To ensure there was no transition effect on the UHPLC system affecting results of subsequent runs, $\mathrm{ACN} / \mathrm{H}_{2} \mathrm{O}$ (30:70) solvent samples were injected between batches.

\subsection{Analytes identification and quantification}

Analytes were quantified after correction of loss during extraction, calculated from mean recovery values of internal standards (clothianidin $\mathrm{d}_{3}$ and thiamethoxam $\mathrm{d}_{3}$ ) and honeybee masses used to extract each sample. Results were expressed in nanogram of analyte per gram of bee (ng/g).

Analytes with values less than three times the signal-to-noise ratio $(\mathrm{S} / N<3)$ of the quantification ion Q3(1) were considered not detected (ND). The designation "lower than the limit of quantification" (<LOQ) was given to samples with values from 3 to 10 times the signal-to-noise ratio $(3<\mathrm{S} / N<10)$ of Q3(1). Values equal or higher than 10 times the signal-to-noise ratio ( $\mathrm{S} / N \geq 10$ ) accounted for levels of analytes considered in the analysis and were reported as absolute numbers. 


\section{RESULTS AND DISCUSSION}

We sought to identify and quantify compounds present in samples of apparently poisoned honeybees, with an emphasis on neonicotinoid and fipronil insecticides, to confirm involvement of compounds speculated to have killed honeybees (Castilhos et al. 2019). Multiple insecticides were detected, with frequent detection of fipronil and neonicotinoids at lethal levels $\left(>\mathrm{LD}_{50}\right)$ in these insects. Pesticides have also been detected at sublethal levels. If these chemicals accumulate in honeybees for prolonged intervals, they can cause colony losses (Kiljanek et al. 2016a, b, 2017; Lu et al. 2014; Pisa et al. 2015).

Many studies have detected multiple pesticides in bees (Botías et al. 2015, 2016, 2017; Hladik et al. 2016; Lambert et al. 2013; Pettis et al. 2013; Sánchez-Bayo and Goka 2014). Insecticide concentrations in the current study were similar to previous reports (Botías et al. 2015, 2016, 2017) for live bee samples; however, those authors investigated bumblebees (Bombus spp.) whereas we analyzed Africanized honeybees (Apis mellifera). Samples from live honeybees had remarkable differences in frequency and level of contaminations by pesticide residues, consistent with a recent publication (Kiljanek et al. 2017) (Figure 2).

The analytical method performed well, with good linearity for calibration curves (>99\%) and adequate detection and quantification limits according to the method used (David et al. 2015). Residue records $<$ LOQ $(3<\mathrm{S} / N<10)$ were excluded from frequency accounting, whereas residue records $\geq \operatorname{LOQ}(\mathrm{S} / N \geq 10)$ were recorded and highlighted (Table S.M. 4 and Table S.M. 5-Supplementary Material). The absence of clothianidin was unexpected, as clothianidin is a commonly used plant protection product (PPP) and a metabolite of thiamethoxam (Meredith et al. 2002). Although clothianidin, thiamethoxam, and imidacloprid are readily metabolized by honeybees (Brunet et al. 2005; Nauen et al. 2003; Laurino et al. 2011; Pistorius et al. 2015) and degradation may occur during storage (Bonmatin et al. 2015; Burrows et al. 2002), at least some residual contaminations were expected (Tables II and III).

Dead honeybee samples had substantially higher concentrations of pesticides than live honeybee samples and the pesticide frequency had an association to honeybee death $\left(\chi^{2}=58.4, p<\right.$ $0.0001)$. Five dead honeybee samples did not contain residues of neonicotinoids and fipronil; perhaps deaths occurred due to other pesticides not targeted in this research (Mullin et al. 2010), synergism or antagonism among various substances, or unknown causes (Sánchez-Bayo and Goka 2014; Spurgeon et al. 2016). Also, 13 live honeybee samples with one pesticide residue detected had levels of contamination $>\mathrm{LOQ}$, without apparent hazardous effects at the moment of collection.

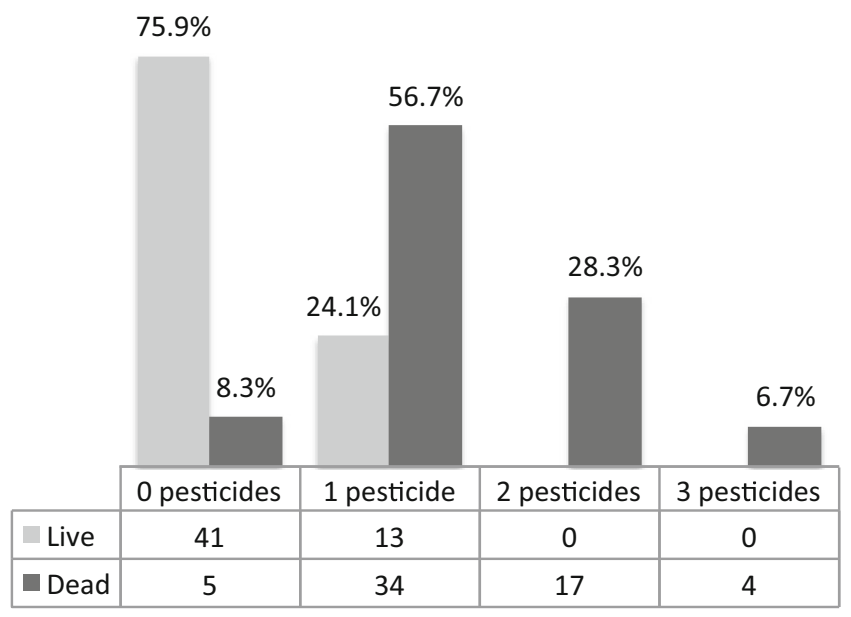

Figure 2. Residue occurrences in samples of live and dead honeybees. 
Table II.. Insecticides detected in 54 samples of live honeybees.

Live honeybee samples

\begin{tabular}{|c|c|c|c|c|c|c|c|c|c|}
\hline \multirow[t]{2}{*}{ Insecticide } & \multicolumn{2}{|c|}{ Frequency } & \multicolumn{5}{|c|}{ Residue concentration (ng/g) } & \multicolumn{2}{|c|}{$\mathrm{LD}_{50}(\mathrm{ng} / \mathrm{g})^{*}$} \\
\hline & $n$ & $\%$ & Min. & Max. & Mean & Median & 95th percentile & Contact & Oral \\
\hline Acetamiprid & 0 & 0.0 & - & - & - & - & - & 80,900 & 143,530 \\
\hline Clothianidin & 0 & 0.0 & - & - & - & - & - & 440 & 40 \\
\hline Dinotefuran & 0 & 0.0 & - & - & - & - & - & 230 & - \\
\hline Imidacloprid & 0 & 0.0 & - & - & - & - & - & 810 & 37 \\
\hline Nitenpyram & 2 & 3.7 & 3.8 & 7.4 & 5.6 & 5.6 & 7.2 & 1,380 & - \\
\hline Thiacloprid & 0 & 0.0 & - & - & - & - & - & 388,200 & 173,200 \\
\hline Thiamethoxam & 3 & 5.6 & 0.6 & 8.2 & 4.0 & 3.1 & 7.7 & 240 & 50 \\
\hline Fipronil & 8 & 14.8 & 0.7 & 6.7 & 2.8 & 1.6 & 6.4 & 59 & 42 \\
\hline
\end{tabular}

*Assuming average honeybee weight 100 mg. Source: Kiljanek et al. (2017), PPDB (2016)

In view of our findings (Tables I and II), we inferred that honeybees suffered acute and chronic poisoning by fipronil and neonicotinoids. Due to its delayed effect, fipronil is metabolized in honeybee body to fipronil sulfone, which is as toxic as fipronil, with potential to accumulate in honeybees in continuous chronic doses over several days, perhaps contaminating the entire hive (DEFRA 2014). Fazekas et al. (2012) concluded that fipronil had the most deleterious effect on colony losses.
Concentrations of neonicotinoids and fipronil in the present study were similar to those in a previous study of live and dead honeybee samples (Kiljanek et al. 2017). Bee colonies contaminated with fipronil died rapidly (Traynor et al. 2016) and there were high fipronil concentrations (>150 $\mathrm{ng} / \mathrm{g}$ ) in dead honeybee colonies in Uruguay (Pareja et al. 2011). In another study (Chauzat et al. 2009), there were low mean fipronil concentrations $(0.5 \mathrm{ng} / \mathrm{g})$ in apiaries with high mortality

Table III.. Insecticides detected in 60 samples of dead honeybees.

Dead honeybee samples

\begin{tabular}{|c|c|c|c|c|c|c|c|c|c|}
\hline \multirow[t]{2}{*}{ Insecticide } & \multicolumn{2}{|c|}{ Frequency } & \multicolumn{5}{|c|}{ Residue concentration (ng/g) } & \multicolumn{2}{|c|}{$\mathrm{LD}_{50}(\mathrm{ng} / \mathrm{g})^{*}$} \\
\hline & $n$ & $\%$ & Min. & Max. & Mean & Median & 95th percentile & Contact & Oral \\
\hline Acetamiprid & 0 & 0.0 & - & - & - & - & - & 80,900 & 143,530 \\
\hline Clothianidin & 0 & 0.0 & - & - & - & - & - & 440 & 40 \\
\hline Dinotefuran & 0 & 0.0 & - & - & - & - & - & 230 & - \\
\hline Imidacloprid & 4 & 6.7 & 4.5 & 16.2 & 9.5 & 8.7 & 15.6 & 810 & 37 \\
\hline Nitenpyram & 0 & 0.0 & - & - & - & - & - & 1,380 & - \\
\hline Thiacloprid & 1 & 1.7 & - & - & - & - & - & 388,200 & 173,200 \\
\hline Thiamethoxam & 20 & 33.3 & 0.8 & 13.6 & 3.3 & 2.2 & 7.9 & 240 & 50 \\
\hline Fipronil & 55 & 91.7 & 1.2 & $23,539.7$ & $2,098.9$ & 22.7 & $13,474.0$ & 59 & 42 \\
\hline
\end{tabular}

*Assuming mean honeybee weight 100 mg. Source: Kiljanek et al. (2017), PPDB (2016) 
(9.1\%), but there was no clear cause and effect. The Colmeia Viva Project (UNESP, UFSCAR 2018) concluded that $67 \%$ of dead honeybee samples were contaminated by multiple pesticides, namely fipronil $(77.1 \%)$ and neonicotinoids $(22.9 \%)$, very similar to current findings and previous reports. Colmeia Viva investigated deaths in São Paulo state, where aerial spraying comprises $75 \%$ of pesticide applications. According to Bombardi (2017), in crops like soybean, corn, sugar cane, citrus, and banana, pesticides aerial spraying is intense. This method of application causes "spray-drift," i.e., pesticide that does not reach the target-culture and disperses in the environment. Although aerial spraying is prohibited in the EU according to Directive 2009/128/EC13, article 9 (EU-Lex 2009), in Brazil, the law $7802 / 1989$ regulates pesticide use (Brasil 1989), and aerial spraying is not specifically prohibited.

Honeybees that pollinated melon plantations had, on average, $5.9 \mu \mathrm{g} / \mathrm{kg}$ of acetamiprid, $26.8 \mu \mathrm{g} / \mathrm{kg}$ of imidacloprid, and $6.0 \mu \mathrm{g} / \mathrm{kg}$ of thiamethoxam; these concentrations were sufficient to cause adverse effects on bees (Silva et al. 2015). Many other authors strongly suggested that pollination of agricultural crops poses high risk to honeybees and may reduce their life expectancy (Castilhos et al. 2019; dos Santos et al. 2018; Pohorecka et al. 2017; Simon-Delso et al. 2017). In Brazil, bee colony losses were speculated to be caused by intense use of pesticides in agricultural areas (Castilhos et al. 2019; dos Santos et al. 2018; Rosa et al. 2015; UNESP, UFSCAR 2018).

\section{CONCLUSIONS}

Dead honeybee samples collected from rural Brazil have several pesticides in a wide range of concentrations and there are associations between deaths and frequency of contamination in honeybees. Live honeybee samples show pesticide concentrations below $\mathrm{LD}_{50}$. The most frequent pesticide found in dead honeybees is fipronil, and it also appears at higher concentrations.

\section{ACKNOWLEDGMENTS}

Authors thank BEE OR NOT TO BE for access to their database, UFERSA for resources and facilities, EVA CRANE TRUST for funding, Arthur David and Cristina Botías for method support, Paulo S. F. Chagas for lab support, John Kastelic for manuscript editing, and beekeepers for supplying samples.

\section{AUTHORS' CONTRIBUTIONS}

KPG managed the project and resources, LSG led research, JLDD and DC performed UHPLC-MS/ MS analyses, GCB performed statistical analyses, and DC collected samples, extracted and run the analytes, and formatted the paper. All authors participated in manuscript writing.

\section{COMPLIANCE WITH ETHICAL STANDARDS}

Conflict of interest The authors declare that they have no conflict of interest.

Les concentrations de néonicotinoïdes et de fipronil trouvées chez les abeilles domestiques associées à l'utilisation de pesticides dans les zones agricoles brésiliennes

Apis mellifera / pertes en colonies / pesticide / UHPLCMS/MS / QuEChERS / paysages ruraux

Neonicotinoide und Fipronilkonzentrationen in Honigbienen, die mit der Verwendung von Pestiziden in brasilianischen landwirtschaftlichen Gebieten in Zusammenhang stehen

Apis mellifera / Kolonieverluste / Pestizid / UHPLC-MS/ MS / QuEChERS / ländliche Landschaften

\section{REFERENCES}

Anastassiades, M., Lehotay, S.J., Stajnbaher, D., Schenk, F.J. (2003) Fast and easy multiresidue method employing acetonitrile extraction/partitioning and "dispersive solid-phase extraction" for the determination of pesticide residues in produce. J. AOAC Int. 86 (2), 
412-431. Available at: http://lib3.dss.go. th/fulltext/Journa 1/J.AOAC\% 201999-2003/J. AOAC2003/v86n2p\%28marapr\%29/v86n2p412.pdf.

Bernhardt, E.S., Rosi, E.J., Gessner, M.O. (2017) Synthetic chemicals as agents of global change. Front. Ecol. Environ., 15 (2), 84-90. https://doi.org/10.1002 /fee. 1450 .

Bombardi, L.M. (2017) Geografia do Uso de Agrotóxicos no Brasil e Conexões com a União Europeia. São Paulo: FFLCH - USP. 296p. Available at: https://www.larissabombardi.blog.br/livros. ISBN: 978-85-7506-310-1

Bonmatin, J-M., Giorio, C., Girolami, V., Goulson, D., Kreutzweiser, D.P., Krupke, C., Liess, M., Long, E., Marzaro, M., Mitchell, E.A.D., Noome, D.A., SimonDelso, N., Tapparo, A. (2015) Environmental fate and exposure, neonicotinoids and fipronil. Environ. Sci. Pollut. Res., 22 (1), 35-67. https://doi.org/10.1007 /s11356-014-3332-7.

Botías, C., David, A., Horwood, J., Abdul-Sada, A., Nicholls, E., Hill, E., Goulson, D. (2015) Neonicotinoid residues in wildflowers, a potential route of chronic exposure for bees. Environ. Sci. Technol., 49 (21), 12731-12740. https://doi. org/10.1021/acs.est.5b03459.

Botías, C., David, A., Hill, E., Goulson, D. (2016) Contamination of wild plants near neonicotinoid seed treated crops, and implications for non-target insects. Sci. Total Environ., 566-567 (6), 269-278. https://doi. org/10.1016/1.scitotenv.2016.05.065.

Botías, C., David, A., Hill, E., Goulson, D. (2017) Quantifying exposure of wild bumblebees to mixture of agrochemicals in agricultural and urban landscapes. Environ. Pollut., 222, 73-82. https://doi.org/10.1016/j. envpol.2017.01.001.

Brasil. (1989) Lei Federal n 7.802, de 11 de julho de 1989. Available at: http:/www.planalto.gov.br/ccivil_03/ LEIS/L7802.htm

Brunet, J-L., Badiou, A., Belzunces, L.P. (2005) In vivo metabolic fate of $\left[{ }^{14} \mathrm{C}\right]$-acetamiprid in six biological compartments of the honeybee, Apis mellifera L. Pest Manag. Sci., 61 (8), 742-748. https://doi.org/10.1002 /ps.1046.

Burrows, H.D., Canle, L.M., Santaballa, J.A., Steenken, S. (2002) Reaction pathways and mechanisms of photo degradation of pesticides. J. Photochem. Photobiol. B Biol., 67 (2), 71-108. https://doi.org/10.1016/S10111344(02)00277-4.

Byrne, F.J., Toscano, N.C. (2006) Uptake and persistence of imidacloprid in grapevines treated by chemigation. Crop Prot., 25 (8), 831-834. https://doi.org/10.1016/j. cropro.2005.11.004.

Casida, J., Durkin, K. (2013) Neuroactive insecticides: targets, selectivity, resistance and secondary effects. Annu. Rev. Entomol., 58, 99-117. https://doi. org/10.1146/annurev-ento-120811-153645.

Castilhos, D., Bergamo, G.C., Gramacho, K.P., Gonçalves, L.S. (2019) Colony losses in Brazil: a 5-year online survey. Apidologie, online version. https://doi. org/10.1007/s13592-019-00642-7.

Castillo-Diaz, J.M., Martin-Laurent, F., Beguet, J., Nogales, R., Romero, E. (2017) Fate and effect of imidacloprid on vermicompost-amended soils under dissimilar conditions: risk for soil functions, structure, and bacterial abundance. Sci. Total Environ., 579 (6), 1111-1119. https://doi.org/10.1016/j. scitotenv.2016.11.082.

Castle, S.J., Byrne, F.J., Bi, J.L., Toscano, N.C. (2005) Spatial and temporal distribution of imidacloprid and thiamethoxam in citrus and impact on Homalodisca coagulata populations. Pest Manag. Sci., 61 (1), 7584. https://doi.org/10.1002/ps.949.

Chagnon M., Kreutzweiser, D., Mitchell, E.A.D., Morrissey, C.A., Noome, D.A., Van Der Sluijs, J.P. (2015) Risks of large-scale use of systemic insecticides to ecosystem functioning and services. Environ. Sci. Pollut. Res., 22 (1), 119-134. https://doi.org/10.1007 /s11356-014-3277-X.

Chauzat, M.P., Carpentier, P., Martel, A.C., Bougeard, S., Cougoule, N., Porta, P., Lachaize, J., Madec, F., Aubert, M., Faucon, J.P. (2009) Influence of pesticide residues on honeybee (Hymenoptera: apidae) colony health in France. Environ. Entomol., 38 (3), 514- 423. https://doi.org/10.1603/022.038.0302.

David, A., Botías, C., Abdul-Sada, A., Goulson, D. (2015) Sensitive determination of mixtures of neonicotinoid and fungicide residues in pollen and single bumblebees using a scaled down QuEChERS method for exposure assessment. Anal. Bioanal. Chem., 407 (26), 81518162. https://doi.org/10.1007/s00216-015-8986-6.

DEFRA - Department for Environment Food and Rural Affairs. (2014) Evidence project final report: interpretation of pesticide residues in honeybees. Available at: http://randd.defra.gov.uk/Default.aspx?Menu= M e n u \& M o d u le $=$ M ore \& L o c a t i o n = None\&ProjectID=18321

dos Santos C.F., Otesbelgue, A., Blochtein, B. (2018) The dilemma of agricultural pollination in Brazil: Beekeeping growth and insecticide use. PLoS ONE, 13 (7), e0200286. https://doi.org/10.1371/journal. pone. 0200286 .

Douglas, M.R., Tooker, J.F. (2015) Large-scale deployment of seed treatments has driven rapid increase in use of neonicotinoids insecticides and preemptive pest management in US field crops. Environ. Sci. Technol., 49 (8), 50885097. https://doi.org/10.1021/es506141g.

EFSA - European Food Safety Authority. (2016a) Conclusion on the peer review of the pesticide risk assessment for the active substance imidacloprid in light of confirmatory data submitted. EFSA J., 14 (11), e4607, 39p. https://doi.org/10.2903/j.efsa.2016.4607.

EFSA - European Food Safety Authority. (2016b) Conclusion on the peer review of the pesticide risk assessment for the active substance clothianidin in light of confirmatory data submitted. EFSA J., 14 (11), e4606, 34p. https://doi.org/10.2903/j.efsa.2016.4606. 
EU-Lex. Official Journal of the European Union. (2009) Directive 2009/128/EC of the European Parliament and of the Council of 21 October 2009 establishing a framework for Community action to achieve the sustainable use of pesticides. Available at: http://data.europa.eu/eli/dir/2009/128/oj

European Commission. (2017) Guidance document on analytical control and method validation procedures for pesticide residues and analysis in food and feed SANTE/11813/2017, rev. 0. Available at: https:/lec. europa.eu/food/sites/food/files/plant/docs/pesticides mrl_guidelines_wrkdoc_2017-11813.pdf

Fazekas, B., Láng, M.W., Déakné, P.P., Csaba, G., Orosz, E. (2012) Pesticide poisoning of honeybees between 2007 and 2011. Magyar Allatorvosok Lapja, 134 (4), 213-220. ISSN:0025004X.

Gonçalves, L.S. (2012a) O desaparecimento das abelhas, suas causas, consequências e o risco dos neonicotinóides para o agronegócio. Mensagem Doce, 117, 2-12. Available at: http://www.apacame.org. br/mensagemdoce/117/artigo1.htm

Gonçalves, L.S. (2012b) Consequências do desaparecimento $(C C D)$ das abelhas no agronegócio apícola internacional e em especial no Brasil. Annals of Encontro sobre Abelhas de Ribeirão Preto, 10. (CDROM version), p. 24-25.

Gonçalves, L.S., Castilhos, D. (2015a) O impacto causado na apicultura e meliponicultura pelo uso indiscriminado de pesticidas, identificado pelo aplicativo BEE ALERT e o declínio dos polinizadores (abelhas) no Brasil. In: Encontro Sobre Abelhas, 11. Ribeirão Preto, SP, Brasil. Anais do... Ribeirão Preto, USP-RP, p. 60.

Gonçalves, L.S., Castilhos, D. (2015b) Application of the electronic device "BEE ALERT" for registering death of honeybees, stingless bees in general and disappearance of honey bees $(C C D)$ in Brazil. In: International Apicultural Congress, 44. Daejeon, Korea. Scientific Program Abstracts. Annals of... Daejeon: Apimondia, p. 218 .

Google Earth. (2017) Geo-locator Software, version: 7.1.7.2602. Available at: https://www.google.com. br/earth/download/ge/agree.html.

Hladik, M.L., Vandever, M., Smalling, K.L. (2016) Exposure of native bees foraging in an agricultural landscape to current-use pesticides. Sci. Total Environ., 542, 469-477. https://doi.org/10.1016/j. scitotenv.2015.10.077.

INCA - Instituto Nacional de Combate ao Câncer. (2015) Posicionamento do Instituto Nacional de Câncer José de Alencar Gomes da Silva acerca dos agrotóxicos. Available at: http://www1.inca.gov. br/inca/Arquivos/comunicacao/posicionamento_do_ inca_sobre_os_agrotoxicos_06_abr_15.pdf

Kiljanek, T., Niewiadowska, A., Semeniuk, S., Gaweł, M., Borzęcka, M., Posyniak, A. (2016a) Multi-residue method for the determination of pesticides and pesticides metabolites in honeybees by liquid and gas chromatography coupled with tandem mass spectrometryHoneybee poisoning incidents. J. Chromatogr. A,
1435, 100-114. https://doi.org/10.1016/j. chroma.2016.01.045.

Kiljanek, T., Niewiadowska, A., Posyniak, A. (2016b) Pesticide poisoning of honeybees: a review of symptoms, incident classification and causes of poisoning. J. Apic. Sci., 60 (2), 5-24. https://doi.org/10.1515/jas2016-0024.

Kiljanek, T., Niewiadowska, A., Gaweł, M., Semeniuk, S., Borzęcka, M., Posyniak, A., Pohorecka, K. (2017) Multiple pesticide residues in live and poisoned honeybees - Preliminary exposure assessment. Chemosphere, 175 (5), 36-44. https://doi.org/10.1016 /j.chemosphere.2017.02.028.

Köhler, H-R., Triebskorn, R. (2013) Wildlife ecotoxicology of pesticides: can we track effects to the population level and beyond? Science, 341 (6147), 759-765. https://doi.org/10.1126/science.1237591.

Lambert, O., Piroux, M., Puyo, S., Thorin, C., L'hostis, M., Wiest, L., Buleté, A., Delbac, F., Pouliquen, H. (2013). Widespread occurrence of chemical residues in beehive matrices from apiaries located in different landscapes of western France. PLoS ONE, 8 (6), e67007. https://doi.org/10.1371/journal. pone. 0067007 .

Laurino, D., Porporato, M., Patetta, A., Manino, A. (2011) Toxicity of neonicotinoid insecticides to honey bees: laboratory tests. Bull. Insectol., 64 (1), 107-113. Available at: http://www.bulletinofinsectology. org/pdfarticles/vol64-2011-107-113laurino.pdf.

Lu, C., Warchol, K.M., Callahan, R.A. (2014) Sub-lethal exposure to neonicotinoids impaired honeybees winterization before proceeding to colony collapse disorder. Bull. Insectol., 67 (1), 125-130. Available at: h t t p : / / w w w . bulletinofins ectology. org/pdfarticles/vol67-2014-125-130lu.pdf.

Maini, S., Medrzycki, P., Porrini, C. (2010) The puzzle of honeybee losses: a brief review. Bull. Insectol., 63 (1), 153-160. Available at: http://www.bulletinofisecto logy.org/pdfarticles/vol63-2010-153-160maini.pdf.

Marrs, T.C. (1993) Organophosphate poisoning. Pharmacol. Ther., 58 (1), 51-66. https://doi. org/10.1016/0163-7258(93)90066-M.

Meredith, R.H., Heatherington, P.J., Morris, D.B. (2002) Clothianidin, a new chloronicotinyl seed treatment for use on sugar beet and cereals: field trial experiences from Northern Europe. In: British Crop Protection Council, pp. 691-696. Available at: http://www. cabdirect.org/abstracts/20033026728.html

Mullin, C.A., Frazier, M., Frazier, J.L., Ashcraft, S., Simonds, R., Vanengelsdorp, D., Pettis, J.S. (2010) High levels of miticides and agrochemicals in North American apiaries: implications for honey bee health. PLoS ONE, 5 (3), e9754, 1-19. https://doi. org/10.1371/journal.pone.0009754.

Nauen, R., Ebbinghaus-Kintscher, U., Salgado, V.L., Kaussmann, M. (2003) Thiamethoxam is a neonicotinoid precursor converted to clothianidin in insects and plants. Pestic. Biochem. Physiol., 76 (2), 55-69. https://doi.org/10.1016/s0048-3575(03)000658 . 
Pareja, L., Colazzo, M., Pèrez-Parada, A., Nieli, S., Carrasco-Letelier, L., Besil, N., Cesio, M.V., Heizen, H. (2011) Detection of pesticides in active and depopulated beehives in Uruguay. Int. J. Environ. Res. Public Health, 8, 3844-3858. https://doi. org/10.3390/ijerph8103844.

Pettis, J.S., Lichtenberg, E.M., Andree, M., Stitzinger, J., Rose, R., Vanengelsdorp, D. (2013) Crop pollination exposes honey bees to pesticides which alters their susceptibility to the gut pathogen Nosema ceranae. PLoS ONE, 8 (7), e70182. https://doi.org/10.1371 /journal.pone.0070182.

Pignati, W.A., de Souza e Lima, F.A.N, de Lara, S.S., Correa, M.L.M., Barbosa, J.R., Costa Leão, L.H., Pignatti, M.G. (2017) Spatial distribution of pesticide use in Brazil: a strategy for Health Surveillance. Ciência \& Saúde Coletiva, 22 (10), 3281-3293. h t t p s : / / d o i.org/10.1590/1413812320172210.17742017 .

Pires, C.S.S., Pereira, F.M., Lopes, M.T.R., Nocelli, R.C.F., Malaspina, O., Pettis, J.S., Teixeira, E.W. (2016) Enfraquecimento e perda de colônias de abelhas no Brasil: há casos de $C C D$ ? Pesq. Agrop. Brasileira, 51 (5), 422-442. https://doi.org/10.1590/S0100-204 X2016000500003.

Pisa, L.W., Amaral-Rogers, V., Belzunces, L.P., Bonmatin, J-M., Downs, C.A., Goulson, D., Kreutzweiser, D.P., Krupke, C., Liess, M., Mcfield, M., Morrissey, C.A., Noome, D.A., Settele, J., Simon-Delso, N., Stark, J.D., Van Der Sluijs, J.P., Van Dyck, H., Wiemers, M. (2015) Effects of neonicotinoids and fipronil on nontarget invertebrates. Environ. Sci. Pollut. Res., 22 (1), 68-102. https://doi.org/10.1007/s11356-014-3471-x.

Pisa, L.W., Goulson, D., Yang, E-C., Gibbons, D., Sánchez-Bayo, F., Mitchell, E., Aebi, A., Van Der Sluijs, J., Macquarrie, C.J.K., Giorio, C., Long, E.Y., Mcfield, M., Van Lexmond, M.B., Bonmatin, J-M. (2017) An update of the Worldwide Integrated Assessment (WIA) on systemic insecticides. Part 2: impacts on organisms and ecosystems. Environ. Sci. Pollut. Res. (online version), 1-49. https://doi.org/10.1007 /s11356-017-0341-3.

Pistorius, J., Wehner, A., Kriszan, M., Bargen, H., Knäbe, S., Klein, O., Frommberger, M., Stähler, M., Heimbach, U. (2015) Application of predefined doses of neonicotinoid containing dusts in field trails and acute effects on honey bees. Bull. Insectol., 68 (2), 161-172. Available at: http://www. bulletinofinsectology.org/ pdfarticles/vol68-2015-161172pistorius.pdf.

Pohorecka, K., Szczesna, T., Witek, M., Miszczak, A., Sikorski, P. (2017) The exposure of honeybees to pesticide residues in the hive environment with regard to winter colony losses. J. Apic. Sci., 61 (1), 105-125. https://doi.org/10.1515/JAS-2017-0013.

PPDB - Pesticides Properties Database. (2016) Online version 7.0. Hatfield: University of Hertfordshire. Available at: http://sitem.herts.ac. uk/aeru/ppdb/en/index.htm.

Rigotto, R.M., Vasconcelos, D.P., Rocha, M.M. (2014) Uso de agrotóxicos no Brasil e problemas para a saúde pública. Cad. Saúde Pública, Rio de Janeiro, 30 (7), 1-3. https://doi.org/10.1590/0102$311 X P E 020714$.

Rosa, A.S., Price, R.I., Calimam, M.J.F., Queiroz, E.P., Blochtein, B., Pires, C.S.S., Imperatriz-Fonseca, V.L. (2015) The stingless bee species, Scaptotrigona aff. depilis, as a potential indicator of environmental pesticide contamination. Environ. Toxicol. Chem., 34 (8), 1851-1853. https://doi.org/10.1002/etc.2998.

Sanches, A.L., Felippe, M.R., Carmo, A.U., Rugno, G.R., Yamamoto, P.T. (2009) Eficiência de inseticidas sistêmicos, aplicados em mudas cítricas, em préplantio, no controle de Diaphorina citri (Kuwayama) (Hemiptera: Psyllidae). Bioassay, 4 (6), 1-7. https://doi.org/10.14295/BA.v4.0.29.

Sánchez-Bayo, F., Goka, K. (2014) Pesticide residues and bees: a risk assessment. PLoS ONE, 9 (4), e99482. https://doi.org/10.1371/journal.pone.0094482.

Schaafsma, A., Limay-Rios, V., Xue, Y., Smith, J., Baute, T. (2016) Field-scale examination of neonicotinoid insecticide persistence in soil as a result of seed treatment use in commercial maize (corn) fields in southwestern Ontario. Environ. Toxicol. Chem., 35 (2), 295-302. https://doi.org/10.1002/etc.3231.

Silva, I.P., Oliveira, F.A.S., Pedroza, H.P., Gadelha, I.C.N., Melo, M.M., Soto-Blanco, B. (2015) Pesticide exposure of honeybees (Apis mellifera) pollinating melon crops. Apidologie, 46 (6), 703-715. https://doi. org/10.1007/s13592-015-0360-3.

Simon-Delso, N., Amaral-Rogers, V., Belzunces, L.P., Bonmatin, J-M., Chagnon, M., Downs, C., Furlan, L., Gibbons, D.W., Giorio, C., Girolami, V., Goulson, D., Kreutzweiser, D.P., Krupke, C.H., Liess, M., Long, E., Mcfield, M., Mineau, P., Mitchell, E.A., Morrissey, C.A., Noome, D.A., Pisa, L., Settele, J., Stark, J.D., Tapparo, A., Van Dyck, H., Van Praagh, J., Van Der Sluijs, J.P., Whitehorn, P.R., Wiemers, M. (2015) Systemic insecticides (neonicotinoids and fipronil): trends, uses, mode of action and metabolites. Environ. Sci. Pollut. Res., 22 (1), 5-34. https://doi.org/10.1007/s11356-014-3470-y.

Simon-Delso, N., San Martin, G., Bruneau, E., Delcourt, C., Hautier, L. (2017) The challenges of predicting pesticide exposure of honeybees at landscape levels. Sci. Rep., 7 (3801), 1-10. https://doi.org/10.1038/s41598017-03467-5

Spadotto, C.A. (2006) Avaliação de riscos ambientais de agrotóxicos em condições brasileiras. Jaguariúna: Embrapa Meio Ambiente. $1^{\text {st }}$ online edition, 20p. Available at: https://www.agencia.cnptia.embrapa. br/Repositorio/documentos 58ID-bpKAg6 MWXm. pdf. Access 15 July 2017. ISSN: 1516-4691

Spurgeon, D., Hesketh, H., Lahive, E., Svendsen, C., Baas, J., Robinson, A., Horton, A., Heard, M. (2016) Chronic oral lethal and sub-lethal toxicities of different binary mixtures of pesticides and contaminants in bees (Apis mellifera, Osmia bicornis and Bombus terrestris). Centre for Ecology and Hydrology. EFSA supporting publication 2016, EN-1076. 66p. Available at: http://onlinelibrary.wiley.com/store/10.2903/sp. efsa.2016.EN-1076/asset/efs31076e.pdf;jsessionid=9 D4012A1CA30623573CF89E5489EEBFC.f01t02 
?v=1\&t=jc2k03dy\&s=78bba77e1d8c8d4ea6a8e4d6 b9090b1352efeaf8

Stevens, S., Jenkins, P. (2014) Heavy costs: weighing the value of neonicotinoid insecticides in agriculture. In: Center for food safety. 20 p. Available at: http://www. centerforfoodsafe ty.org/files/neonic-efficacy_digital_29226.pdf

Suchail, S., Guez, D., Belzunces, L.P. (2000) Characteristics of imidacloprid toxicity in two Apis mellifera subspecies. Environ. Toxicol. Chem., 19 (7), 19011905. https://doi.org/10.1002/etc.5620190726.

Traynor, K.S., Pettis, J.S., Tarpy, D.R., Mullin, C.A., Frazier, J.L., Frazier, M., vanEnngelsdorp, D. (2016) In-hive pesticide exposome: assessing risks to migratory honeybees to in-hive pesticide contamination in the Eastern United States. Sci. Rep., 6, 33207. https://doi.org/10.1038/srep.33207.
UNESP, UFSCAR. (2018) Mapeamento de abelhas participativo. In: SINDIVEG: Projeto Colmeia Viva. 22p. Available at: http://projetocolmeiaviva.org. br/wpcontent/uploads/2018/10/Relatorio_final_WEB30abr2018.pdf

Wood, T., Goulson, D. (2017) The environmental risks of neonicotinoids pesticides: a review of the evidence post-2013. Paris: Greenpeace France. 7-8. 87p. Available at: https://www.greenpeace.ch/wpcontent/uploads/2017/01/neonicotinoid-pesticides_final_single_web_FINAL.pdf

Publisher's note Springer Nature remains neutral with regard to jurisdictional claims in published maps and institutional affiliations. 